\title{
Maxillary Sinus Cancer pT4 TNM Finding v8
}

National Cancer Institute

\section{Source}

National Cancer Institute. Maxillary Sinus Cancer pT 4 TNM Finding v8. NCI Thesaurus. Code C133038.

Maxillary sinus cancer with moderately advanced or very advanced local disease. (from AJCC 8th Ed.) 